九州大学学術情報リポジトリ

Kyushu University Institutional Repository

\title{
Higher Education in Private Universities in Bangladesh : A Model for Quality Assurance
}

Barai, Munim K.

Ritsumeikan Asia Pacific University

Bala, Swapan K.

Department of Accounting and Information Systems, University of Dhaka

Suzuki, Yasushi

Ritsumeikan Asia Pacific University

Saha, Bidyut B.

Kyushu University Program for Leading Graduate School, Green Asia Education Center, Kyushu University | International Institute for Carbon-Neutral Energy Research (WPI-I2CNER), Kyushu University

https://doi.org/10.5109/1544077

出版情報 : Evergreen. 2 (2)，pp.24-33，2015-09. Green Asia Education Center バージョン：

権利関係 : 


\title{
Higher Education in Private Universities in Bangladesh: A Model for Quality Assurance
}

\author{
Munim K. Barai ${ }^{*}$, Swapan K. Bala ${ }^{2}$, Yasushi Suzuki ${ }^{1}$, Bidyut B. Saha, ${ }^{3,4 *}$ \\ ${ }^{1}$ Ritsumeikan Asia Pacific University, 1-1 Jumonjibaru, Beppu, Oita 874-8577, Japan \\ ${ }^{2}$ Department of Accounting and Information Systems, University of Dhaka, Dhaka 1000, Bangladesh \\ ${ }^{3}$ Kyushu University Program for Leading Graduate School, Green Asia Education Center \\ Kyushu University, Kasuga-koen 6-1, Kasuga-shi, Fukuoka 816-8580, Japan \\ ${ }^{4}$ International Institute for Carbon-Neutral Energy Research (WPI-I2CNER), Kyushu University
}
*Authors to whom correspondence should be addressed,
E-mails: baraimk@apu.ac.jp (MKB)
saha.baran.bidyut.213@m.kyushu-u.ac.jp (BBS)

(Received June 15, 2015; accepted September 14, 2015)

\begin{abstract}
With the globalization pushed by a network of close communications, a new dynamic and global centric paradigm of education is also evolving. This paradigm is highly sensitive to the quality aspect of education as the stakeholders have a diversified demand from it to achieve. In Bangladesh, the failure of the public universities to meet the growing demand for higher education has led to the establishment of universities by the private bodies. Now about 60 percent of the total campus-based students have been studying in the private universities. Though the number of private universities has increased very rapidly, the quality aspect of their education has become a matter of important concern. This study identifies and examines some of the existing quality deficiencies of the private universities in Bangladesh. It then proposes a model that includes a number of important variables upon which a quality measurement scale could be developed to assess the level of quality of education in higher learning institutions, particularly the private universities in Bangladesh.
\end{abstract}

Keywords: Bangladesh, higher education, private university, quality assurance

\section{Introduction}

With the emergence of a global network of close communications, the education system in most of the universities in the world is experiencing significant changes. The new paradigm of education is dynamic, inclusive, more technology oriented and closer to the demand of the market. Moreover, it has no longer remained a nation-centric approach, rather becoming a global-centric activity due to the mobility of persons and expertise internationally. The new paradigm has been transformed from exclusion to inclusion, classroom to anywhere, fixed time to anytime, teacher to learner, "you learn what we offer" to "we offer you what you want to learn," education as one-time activity to education as a lifelong activity, educational institution as a place to as an arrangement, teacher as instructor to teacher as facilitator, lecture-centric to technology-centric delivery mode, and state-driven activity to market driven activity (Prasad, 2002: 9).
But the development in the educational arena is now concentrating on the quality and today's discussion on education is dominated by quality issues as well. This has been widely influenced by the emergence of critical role of knowledge in development, massive expansion of education system, limited resources, competitive global environment, influence of industrial practices, and new expectations of students and society and other stakeholders like teachers, employers, governments (Prasad, 2002: 9). They all are looking at quality from different perspectives - students for success in examinations; teachers from the viewpoint of the acquisition of knowledge; employers from the work skills of the employees; governments from the value for money and the society may be looking for a good citizen.

So it becomes necessary to have performance indicators of quality education developed for different components or operational structures of a university. For practical use, the performance indicators could be of input indicators, process indicators and output indicators. 
However, the specialty of an institution may influence the type of performance indicator it would apply. Nonetheless, it should apply quality assurance in both internal and external quality assurance measures. While the internal process brings in-depth knowledge, participation and opportunity for continuous improvement, the external quality assurance measure brings credibility, expertise and different perspectives. The combination of both may be necessary for an effective quality assurance system.

In the context of Bangladesh, the higher education scenario has significantly been transformed over the last forty-four years after liberation. In fact, Bangladesh kept the higher education sector in the public domain for a couple of decades. But an important development took place with the enactment of the Private University Act in 1992 that allowed private bodies to establish universities. The effect of this could be seen from the fact that as of July 2015 there were 68 academically active private universities with 20 more in the queue to join. They are operating along with another 37 public universities offering general, science and technology education. Due to the emergence of private universities, the transformation of the higher education sector in Bangladesh is evident. For example, in 2004 the total number of students in public universities (excluding of the National University and the Bangladesh Open University) stood at 78,192 against 32,791 students in the private universities (UGC, 2004). Since then, the total number of students studying in the private universities has increased to 0.33 million in 2013 (UGC, 2013). In other words, the enrollment in the private universities has reached 60 percent of total students in the campus-based universities (Haque, 2014). But there seems to have further space for more universities in Bangladesh as the ratio of university enrollment of the age cohort (18-25 years) has just reached 5 percent in Bangladesh, while in India the same ratio is 15 percent, South Korea 50 percent and Singapore 100 percent (Haque, 2014).

However, the quality aspect of education has emerged as an important concern due to the rapid expansion of private universities in the past couple of decades. Though the initial response of the guardians and their student-wards to these universities was full of doubts and skepticism, a change in perception has taken place in the meanwhile. Presently, they have gained a level of acceptability and confidence in the society as a whole, but the change of perception is not without quality concern. This is because most of the private universities have been suffering from a number of problems although some of them have attained a high standard of education. The objective of the paper is to identify some major deficiencies in private universities in Bangladesh that hamper the quality of their education. In doing so, the paper also aims to include a set of variables in a model that can be used through quantification on some measurement scales to assess the quality level of education offered by the higher educational institutions, including the private universities in Bangladesh.

The rest of the paper has been divided into four parts. Part two of the paper contains a brief literature review. Part three identifies some problems that are hindering the quality assurance of private Universities in Bangladesh. Part four gives a model to include a list of variables to measure the quality standing of a higher educational institution. They have been positioned in a diagram as per their perceived priority and importance. The paper concludes in part five with some suggestive measures to overcome the existing quality of education problems in the private universities in Bangladesh.

\section{Literature Review}

A large number of studies are available on the quality and its assurance at different levels of education in the world. To be contextual, we will mostly focus on some of them that deal with the quality assurance of education at the tertiary level.

To begin with, UNICEF (2000) tries to identify quality of education as the quality of learners with commitment and interest to explore their potentials; environments that are healthy, safe, protective and gender-sensitive, and provide adequate resources and facilities; content that is reflected in relevant curricula and materials for the acquisition of basic skills, attitude and knowledge; processes through which effective and student-centered teaching learning and meaningful assessment to facilitate attainment of learning and reduce disparities; and outcomes that encompass knowledge, skills and attitudes, and are linked to national goals for education and positive participation in society (UGC, 2014). However, in an ever-changing environment the definition of and requirements for quality education are also changing. Now, quality university education should have some aims like offering a systematic assurance to the internal academic community of a university that its provision is excellent, providing a means of accountability to external stakeholders for quality, standards and value for money and giving opportunities for the identification and transmission of sound practice (Harris and Sullivan, 2002: 23). Thus, academic quality assurance seeks to address a diverse range of interests. Indeed, the quality assurance mechanism has to ensure that the development and teaching of subjects take full account of contemporary advances in knowledge; it shows concern for costs, economic competitiveness and focuses on customer satisfaction (Barai, 2006). Given the aims, the first level quality requirements are mainly related to particular categories of human agents, and, of course, the material resources involved in the process. The important factors where quality is considered to be important are policy making, management academic and support staff, student intake, soft and hard infrastructures, etc. These tend to the second level quality requirements, which flow from the first set of variables, like quality of course and programs, delivery systems, support services, 
evaluation schemes and so on (Ahmed et al., 2002: 39).

Actually, the focus of quality assurance should be significant in the entire exercise. It may be on research, teaching, the student experience or academic standards, and the quality assurance systems developed by individual institutions will reflect the balance of emphasis of their missions. So, quality higher education may focus on socially relevant programs and courses, intensive teaching and learning process with updated quality learning materials, valid and reliable evaluation system, high level of research, use of new educational technologies, efficient support services, quality teachers as catalytic agents of development and so on (Prasad, 2002: 11). In evolving the parameters, educational institutions need to focus more broadly on the following academic quality issues: research, teaching quality with the required academic standard, learning and social environments (support staff and physical resources) of the institution. The library as a service, sophistication of levels of equipment, admissions process, and the arrangements for the supervision and examination of research degree candidates, etc. become important (Harris and Sullivan, 2002: 23).

Interestingly, a debate lingers - can total quality management (TQM) is maintainable for quality assurance in the academic arena? The concept is derived from industrial practices. Prominent Quality Management systems such as the Malcolm Baldridge National Quality Award in the USA, European Quality Management Award, Deming Prize (Japan) and ISO 9000 Quality Management Code of Practice tend to adopt variations of two basic methodologies, Total Quality Management (TQM) and Conformance to Specification. Both challenge the participating organization to improve continually quality in a number of inputs, process and output dimensions that have been found to be critical to achieving a quality organization (Hope, 2002:16). Undoubtedly, this is a highly mechanized output-based method. Then could or should it be applied in the academic institutions where the basis of the relationship between the offerors and receivers is qualitative? Indeed, the conformance with specification could be too rigid a method to be employed in the education system. "Zero defect" could be a management tool in organizations dealing with materials and not human beings. Thus, the universities should strive to ensure that their academic activities are characterized by the principles of 'right first time' and 'continuous improvement' with such dynamism that fulfills the requirements of the students. Though some of the ideas of TQM may enhance quality assurance, following it in toto seems impossible as dealings with human being cannot ideally be guided by a concept that predominantly deals with the material aspect of quality management in organizations. Moreover, most of the higher education quality assurance agencies around the world have developed their own guidelines and quality assurance frameworks to guide institutions in preparing for the periodic external reviews or audits that are a feature of most developed higher education systems (Barai, 2006). However, the TQM approach might be related to education with respect to 'service quality', since the education is usually considered to be a 'service'. The most important dimensions of service quality include: time, timeliness, completeness, courtesy, consistency, accessibility and convenience, accuracy, and responsiveness (Parasuraman, Zeithaml and Berry, 1988; vide Dean and Evans, 1994: 10).

Looking at different countries, we find that they have different practices to maintain and improve the quality of education, particularly the higher education. Some leaders in the practices of quality assurance for higher education are the UK, the USA and Australia. In fact, the US system of higher education has created most of the best academic institutions in the world because of the competent professionals who are involved with creating, providing and improving the teaching methods making learning dynamic and interactive. The programs leading to degrees maintain the integrity of substantive and coherent curricula with defined learning outcomes. The institutions accept the obligation to address student needs related to, and to provide the resources necessary for, their academic success and responsibility for the education provided in their name. They regularly undertake the assessment and improvement of their quality, giving particular emphasis to student learning. Even the institutions voluntarily subject themselves to peer review. The resulting statement of the best practices relates to five key areas of institutional activity relevant to both face-to-face and technology oriented education. These are institutional context and commitment, curriculum and instruction, faculty support, student support, evaluation and assessment (Hope, 2002: 20).

However, the mainstream literature is mostly silent on the profit-motivation of education in the private sector. According to King, the fastest-growing form of private higher education is for-profit institutions. They regard education "as a commodity for which individuals are prepared to pay a price that enables a profit to be made by investors" (King, 2003: 3). The University of Phoenix is a well-known international case of this trend. Bev Thaver noted a movement in the direction of a greater presence of for-profit institutions with an emphasis on business courses (Thaver, 2003). As consequence of the strong market orientation of commercial institutions is that such institutions, as Levy has formulated it, "rarely assume or claim to assume academic elite roles complete with doctoral education, basic research, large laboratories or libraries, or mostly full-time academic staff' (Levy, 2002). Their sensitivity to market signals means that commercial institutions tend to mount courses for which employment avenues are clear and sure (Michelsen, 2008). In Bangladesh, the private universities by law are non-profit making institutions. But the promoters of the private universities are engaged in different manipulative activities through which they milk the system to their financial and non-financial benefits. 
Though the private universities in Bangladesh are mostly modeled after the US higher education system, assessment of the quality of their education is not that positive. A University Grants Commission (UGC) of Bangladesh report finds that though the scope of higher education expanded remarkably with the increasing number of universities both in private and public sector, the quality of education has not improved to the desired standards in Bangladesh. This is assessed by the difficulties the graduates have been facing to get gainful employment in highly competitive domestic and international job markets where quality makes a difference. Failure of a large number of graduates to get gainful employment creates frustration in the mind of graduates and creates an imbalance in the society (UGC, 2014).

\section{Status of Quality Assurance in Private Universities in Bangladesh}

In fact, the higher education sector of Bangladesh was a monopoly of the public universities. Their main objectives were the creation, acquisition and the dissemination of knowledge to the students. But they failed to deliver the first and subsequently their number proved to be insufficient to meet the increasing demand for higher education from the growing population. Their failure on both accounts created the avenue for the private sector to operate universities in Bangladesh and the Private University Act 1992 (PUA-92) was passed.

At the initial stage, the pioneers of the private universities including the teachers faced various problems. Acceptability was one of them. Many people including well-known educationists thought since higher education is a public good, the government should continue to enjoy the monopoly in providing higher education. They also thought the social risks were too high. But it has now been proved that in an enabling environment the private sector can run universities along with business, industries, schools, colleges, hospitals or non-government organizations (Siddiqi, 2002: 168).

North South University, the first government-approved private University was established in 1992. The government approved as many as 16 universities by mid-1996. By 2006, there were 53 approved private universities. Side by side, there had been a heavy rush of students for places in the universities, particularly in those that have earned the national and international recognition since 1992. The number of candidates seeking admission has consistently been increasing and reached 328,736 in 2013 from 32,791 in 2000. The recent facts about students pursuing higher education in universities have been given in Table 1 .

Table 1: Facts on University-Level Education up to 2013.

\begin{tabular}{|l|r|r|r|r|r|}
\hline \multicolumn{1}{|c|}{ University Type } & \multicolumn{2}{|c|}{ Public University } & \multicolumn{2}{r|}{ Private University } & \multicolumn{1}{c|}{ Total } \\
\hline $\begin{array}{l}\text { Number of universities } \\
\text { approved }\end{array}$ & 37 & $80^{* *}$ & 117 \\
\hline $\begin{array}{l}\text { No. of universities with } \\
\text { academic activities }\end{array}$ & 34 & & 68 & & 102 \\
\hline Total students & $2,020,549^{*}$ & & 328,736 & & $2,349,285$ \\
\hline Teacher-student ratio & $1: 19$ & & $1: 25$ & & \\
\hline Students who obtained & & \% of Total & & \% of Total & \\
\hline degrees: & 158,908 & & 3,952 & & 162,860 \\
\hline Bachelor (Pass) & 115,658 & 68.0 & 269,114 & 99.2 & 384,772 \\
\hline Bachelor (Honors) & 11,332 & & 53,204 & & 64,536 \\
\hline Bachelor (Technical) & 129,092 & & -- & & 129,092 \\
\hline Masters & 1,933 & 31.6 & -- & 0.0 & 1,933 \\
\hline Masters (Technical) & 1,690 & & -- & & 1,690 \\
\hline M.Phil./Ph.D. & 1,931 & 0.5 & 2,466 & 0.8 & 4,397 \\
\hline $\begin{array}{l}\text { Diploma/Certificate/ } \\
\text { Postgraduate Degree }\end{array}$ & $\mathbf{4 2 0 , 5 4 4}$ & 100.0 & $\mathbf{3 2 8 , 7 3 6}$ & 100.0 & $\mathbf{7 4 9 , 2 8 0}$ \\
\hline Total Degree-holders & & & & & \\
\hline
\end{tabular}

Notes:

* Information for public universities includes students of National University $(1,319,438)$ and Open University $(243,928)$. The mainstream 32 public universities had a total of 210,060 students in 2013.

${ }^{* *}$ As of July 2015, this number is 88 (A list of private universities is available at www.ugc.gov.bd).

Source: Compiled. Data from the UGC Annual Report 2013. 


\subsection{The Qualitative Attributes of Private Universities - A Critical Look}

In case of the private universities of Bangladesh, the relevant criteria to measure the quality can be derived from the provisions of the related statutes. The PUA-92 is the first statute enacted in August 1992 to establish and regulate the private universities, which was amended in 1998. In July 2010, the Private University Act 2010 (PUA-2010) has been enacted repealing the PUA-92. An examination of the Preamble and Provisions of the PUA-92 and its Amendments reveals that the government expects the private universities to achieve five objectives:

- meeting (at least partly) the growing demand for higher education;

- extending the scope of higher education;

- making higher education available to the common people (at affordable costs and without a profit motive);

- increasing the supply of highly skilled manpower for economic development of the country, and expanding quality education.

Now the question is: have the private universities been able to meet these objectives?

In the PUA-92, the provision of quality of education was in section 15 , under which plans, teaching methods, syllabuses and teaching standards relating to teaching programs of private universities were required to be approved by the UGC. In 1998, under the amended provision section 15, approval requirement from the UGC was inserted for additional faculties/schools or departments or additional teachers required for running those faculties/departments. In the PUA-2010, a separate section (section 36) is for ensuring the qualitative standard of education. In accordance with this provision, every private university shall have an Internal Quality Assurance Cell or Unit for ensuring the qualitative standard of education and there must be a separate statement on the steps taken in this regards in its annual report. As per section 38 of the PUB-2010, a national distinct and independent Accreditation Council will be established with a view to achieving the objective of quality education in private universities.

We must, however, note that due to various practical constraints, private universities have limited capacity to play the roles they are expected to do. But there are indicators that confirm that a trend has been set up. Most of the universities are trying, in their limited way, to achieve these goals. The list of subjects on which degrees are offered has also become somewhat longer to include new subjects like computer engineering, MIS (Management Information Systems), civil engineering, electrical engineering, textile engineering, architecture, environment, development studies, English language and literature, physics, electronics, physical \& community medicines etc. Besides, most of the better-running universities have expanded the programs from undergraduate to graduate programs. In almost all cases, the programs offered are market-driven. It is also true that most of these universities heavily concentrate on Business Administration and Computer Science/IT (Information Technology), raising the eyebrow of some people who question the validity of an institution as a University that just offers degrees in four or five disciplines.

Practically, there is no recognized quality assurance (QA) mechanism for public and private universities in Bangladesh at present. To address this, in 2009 the UGC and the Ministry of Education prepared and launched the Higher Education Quality Enhancement Project (HEQEP) with the financial support of the World Bank. Based on the above developments, a Quality Assurance Unit (QAU) within the organizational structure of UGC was created under HEQEP to initiate the QA mechanism in Bangladesh's HEIs (Higher Educational Institutions). As a first step in this endeavor, the HEQEP has also supported the establishment of Institutional Quality Assurance Cells (IQACs) in universities. The QAU will function as a temporary council until the formation of the national Quality Assurance and Accreditation Council, Bangladesh (QAACB) in 2016 (UGC, 2014, pp. xiii-xv).

With this background, let us have a look on the quality aspect and its maintenance of private universities in Bangladesh. In the endeavor, we raise some of the vital concerns though they do not form an exclusive list:

a. Quality of Teaching: Offering good academic programs of the national and international standard is a necessary condition but not a sufficient condition to assure a quality education. The well-meaning curricula may not produce good results if the University does not or cannot hire adequately qualified, experienced and committed teachers to teach the courses. It is also considered that at least 70 to 80 percent of teachers should be full time to assure quality teaching. The UGC reports that in 2004, of the total teachers employed about 61 percent teachers was full time. Over the years, the position has improved to 67.5 percent full-time teachers in 2013 (UGC, 2013). Although the ability to attract and retain good full-time teachers of few top universities has increased, the general situation still continues to be less than satisfactory. The fact remains that the supply pool of the good teachers has remained almost limited, competition between the private universities to hire teachers has increased. Teachers from public universities continue to dominate the faculty list with a few exceptions.

b. Recruiting and Retaining Qualified Teachers: Most of the private universities claim that they follow the US education system. Logically, they prefer to recruit teachers who are familiar with the US system. But this adds a problem. Most of the Bangladeshi graduates do not have a clear idea of the US education system. Although qualified otherwise, they 
become weaker candidates for better private universities. At universities like NSU and few others, these teachers would be considered inadequately qualified because of their weak English grounding. That's why many private universities are finding it difficult to recruit teachers having minimum qualifications set by the UGC.

c. Teacher's Capability of Teaching and Research: Teaching is a special skill and effective teaching skill is necessary to maintain the quality of the university. Therefore, it is desirable that some mechanism be instituted to determine the teaching ability and or commitment of the teachers. Two such mechanisms are (1) students' evaluation and (2) peers' evaluation. In line with the American system, some private universities, as a matter of routine, administer students' evaluation. Though the purpose of such evaluation is to help the teacher improve his/her teaching skill, but in reality how far this has been able to improve the skills is subject to a question as little follow-up measures are taken in most of the universities on the basis of the evaluation. Quality research is another gray area for the faculty of private universities. Consequently, citation of their research works is yet to come to any assessment parameter.

d. Transparency in Grading System: In the American system, one examiner, namely the class teacher concerned, is the single and final assessor. This has merits and demerits. One demerit is that a particular student may be favored unduly or deliberately victimized. The single and final assessor process may have some inevitable negative consequences which the private universities are still overlooking.

e. Faculty Development Program: It is necessary that the universities take effective initiatives to reduce the gap between the supply and demand of teachers. One way is to undertake an extensive faculty development program. Unfortunately, only a few private universities in Bangladesh has reached the stage that enables them to go for a massive faculty development program to enhance the capability of teaching and research of the faculty.

f. Quality of Input: Though the situation has improved in recent years, still the common experience is that most of the candidates who seek admission into private universities, in general, belong to the lower end of merit and preparedness. It seems that best of the students passing HSC (Higher Secondary Certificate) examinations, at first, try to get admission into the public universities. It is well known that the public universities can accommodate hardly about a quarter of the students seeking admission. Moreover, many of the meritorious students cannot afford to go to the private universities because of the high tuition and other fees. Again, some less successful universities have a tendency to admit students by administering no admission tests. Thus, for most private universities, producing high-quality output (graduates) has still remained a difficult task.

g. Cost of Courses: Most of the universities promise to impart world-class education at reasonable costs. But this has remained beyond the reach of the mid and low-income people in the country. The private universities still carry the stigma of "for the wards of the well-off people" and may continue with it in the near future.

h. Infrastructure - Campus, Building etc.: Currently, a small number of private universities have their own campuses, and a smaller of them have adequate facilities required to run a modern university efficiently. These facilities include well-designed classrooms equipped with modern teaching aids like overhead projector, videocassette players, multimedia projector, computer terminals connected to LAN, rich libraries with complete automation, computer and other labs etc. It must be realized that for quality assurance, good teachers must teach good academic courses in good teaching-learning environment. The students must have easy access to the computer network so that they can browse and if necessary, download information/documents that help their learning process. The library should have both digital and hard copies of books of the latest edition, journals of international repute and other reading materials.

i. National and International Recognition: For quality assurance, national and international recognition is essential. The approval of UGC is one such recognition. But for private universities it is not enough. Though many private universities claim to have credit transfer arrangement and membership of different accreditation bodies, most of them are seen making tall or false claims.

j. Governance and Management Style: Most of the universities suffer from both capable management and good governance. Currently, they do not have "approved" statutes as well. This creates managerial problems which ultimately affect quality. In the absence of good governance and efficient management, the quality of the university will suffer.

\section{Quality Assurance - A Proposed Model}

The discussion above influenced us to make an effort to identify and list the variables and sub-set within them to develop a model for the quantification of quality education existing in any university including the private universities in Bangladesh. Importantly, the quantification of these variables is not easy and the variables that have been included do not make the list an exclusive one. In Table 2, we have divided our item-variables into 8 major categories. The major variables included are: policy making quality, management quality, quality of infrastructure, quality of academic environment, quality of student-intake, quality 
of academic environment, quality of curricula and programs, quality of support services and quality of graduates (education). Of them, the quality of student-intake is considered to be input and quality of graduates is the output. The other factors combined constitute the process. Relevant scale for measurement and points to be assigned on the scale as per importance and relevance of the variables could be developed after a through exercise. But we can begin the quality of education as flow process (Figure 1) where quality of student-intake is considered as the input which is processed by seven principal variables to bring out the output (quality of graduates). Understandably, the rigor and the fineness of the output will be determined by the processing factors used.

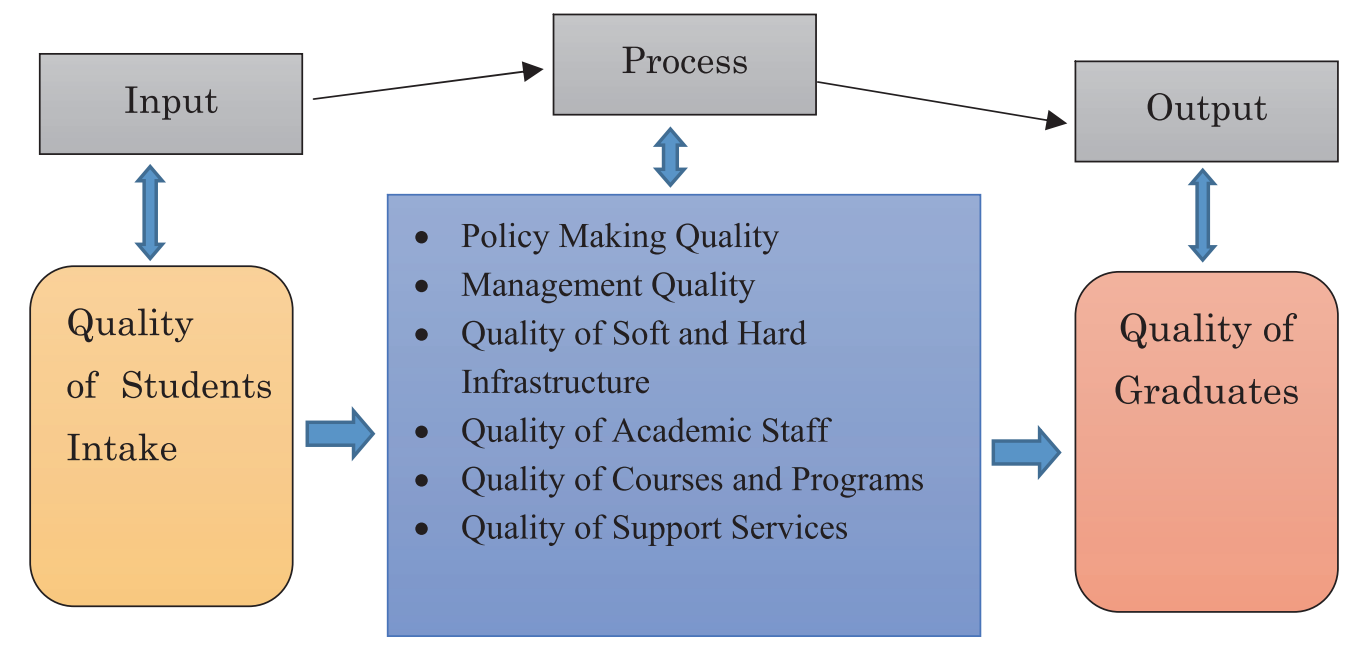

Figure 1: Quality of Education - The Input-Output Process.

Source: Authors' construction.

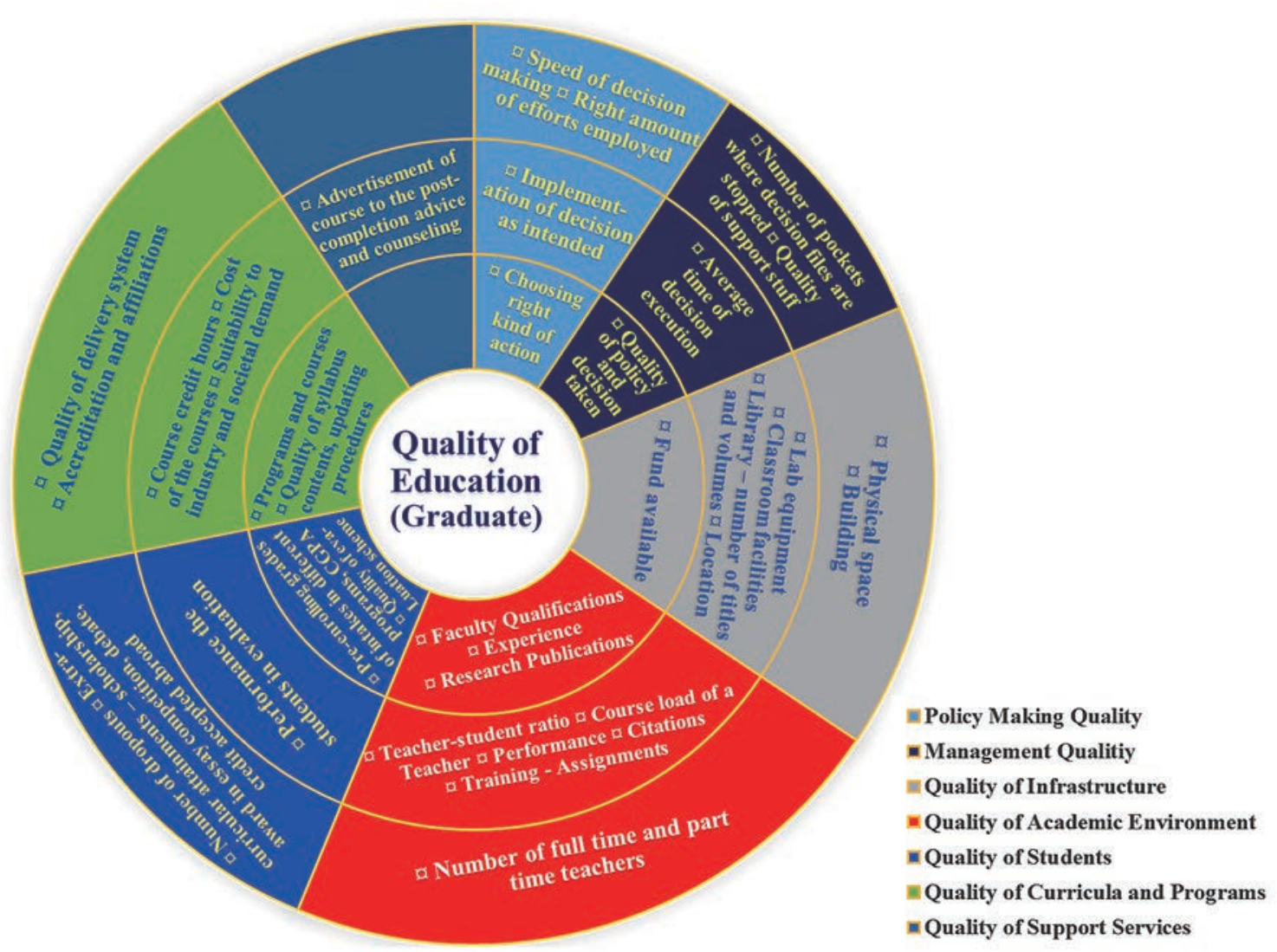

Figure 2: Model for Quality of University Education Assessment.

Source: Authors' construction. 
But all the elements of the variables used for quality university products are not equally important. Keeping that point in mind, we have prepared Figure 2 on the basis of the list in Table 2 to place the elements of principal variables in a four-layer circle. The central layer of the circle is the gravity point that constitutes the quality of education (graduates). Based on that we have placed our identified elements of each variable in the second, third and fourth layer of the circle. In the circle, the more closure an element is to the center, the more important it is for quality education and vice versa. Arguably, there could be differences in opinion on the preference or importance of the variable and elements within them and we are open to it.

As told earlier, we have constructed Figure 2 from Table 2 where we have categorized our assessment variables and placed the elements therein in the layers

Table 2: Quality of Education Assessment Variables.

\begin{tabular}{|c|c|c|c|c|c|c|c|}
\hline $\begin{array}{l}1^{\text {st }} \text { Layer } \\
\text { (Output) }\end{array}$ & \multicolumn{7}{|c|}{$\begin{array}{l}\text { Quality of graduates (education): Reflected by the Internship Offer from Reputed Organizations, } \\
\text { Direct Recruitment by Valued Employers, Peer Referrals for Employment. }\end{array}$} \\
\hline $\begin{array}{l}\text { Quality } \\
\text { Varia } \\
\text { ble }\end{array}$ & Management & $\begin{array}{l}\text { Policy- } \\
\text { making }\end{array}$ & $\begin{array}{l}\text { Academic } \\
\text { environme } \\
\text { nt }\end{array}$ & $\begin{array}{l}\text { Infrastructu } \\
\text { re }\end{array}$ & $\begin{array}{l}\text { Student-intak } \\
\text { e }\end{array}$ & $\underset{\text { programs }}{\text { Curricula }} \&$ & $\begin{array}{l}\text { Support } \\
\text { services }\end{array}$ \\
\hline $2^{\text {nd }}$ Layer & $\begin{array}{l}\text { Choosing } \\
\text { right } \\
\text { kind of } \\
\text { action }\end{array}$ & $\begin{array}{l}\text { Q Quality } \\
\text { of policy } \\
\text { and } \\
\text { decision } \\
\text { taken }\end{array}$ & $\begin{array}{l}\text { Q Faculty } \\
\text { Qualification } \\
\text { s } \\
\text { a Experience } \\
\text { a Research } \\
\text { Publications }\end{array}$ & $\begin{array}{l}\text { a Fund } \\
\text { available }\end{array}$ & $\begin{array}{l}\text { a Pre- } \\
\text { enrolling } \\
\text { grades } \\
\text { of intakes in } \\
\text { different } \\
\text { programs, } \\
\text { CGPA } \\
\text { a Quality of } \\
\text { evaluation } \\
\text { scheme }\end{array}$ & $\begin{array}{l}\text { Programs } \\
\text { and courses } \\
\text { Quality of } \\
\text { syllabus } \\
\text { contents, } \\
\text { updating } \\
\text { procedures }\end{array}$ & \\
\hline $3^{\text {rd }}$ Layer & $\begin{array}{l}\text { Implementat } \\
\text { ion of } \\
\text { decision as } \\
\text { intended }\end{array}$ & $\begin{array}{l}\text { a Average } \\
\text { time of } \\
\text { decision } \\
\text { execution }\end{array}$ & $\begin{array}{l}\text { Teacher-stud } \\
\text { ent ratio } \\
\text { a Course } \\
\text { load of a } \\
\text { Teacher } a \\
\text { Performance } \\
\alpha \text { Citations } \\
\text { a Training - } \\
\text { Assignments }\end{array}$ & $\begin{array}{l}\text { Lab } \\
\text { equipment } \\
a \\
\text { Classroom } \\
\text { facilities } \not \\
\text { Library - } \\
\text { number of } \\
\text { titles and } \\
\text { volumes } \not \\
\text { Location }\end{array}$ & $\begin{array}{l}\text { o } \\
\text { Performance } \\
\text { the students } \\
\text { in evaluation }\end{array}$ & $\begin{array}{l}\text { Course } \\
\text { credit hours } 0 \\
\text { Cost of the } \\
\text { courses } 0 \\
\text { Suitability to } \\
\text { industry and } \\
\text { societal } \\
\text { demand }\end{array}$ & $\begin{array}{l}\text { A } \\
\text { Advertisement } \\
\text { of course to } \\
\text { the } \\
\text { post-complet } \\
\text { ion advice } \\
\text { and } \\
\text { counseling }\end{array}$ \\
\hline $4^{\text {th }}$ Layer & $\begin{array}{l}\text { Speed of } \\
\text { decision } \\
\text { making d } \\
\text { Right } \\
\text { amount of } \\
\text { efforts } \\
\text { employed }\end{array}$ & $\begin{array}{l}\text { Number } \\
\text { of pockets } \\
\text { where } \\
\text { decision } \\
\text { files are } \\
\text { stopped } \\
\text { \& Quality } \\
\text { of support } \\
\text { stuff }\end{array}$ & $\begin{array}{l}\text { Number of } \\
\text { full time and } \\
\text { part time } \\
\text { teachers }\end{array}$ & $\begin{array}{l}\text { a Physical } \\
\text { space } \\
\text { a Building }\end{array}$ & $\begin{array}{l}\text { Number of } \\
\text { dropouts } \alpha \\
\text { Extra-curricu } \\
\text { lar } \\
\text { attainment- } \\
\text { scholarship, } \\
\text { award in } \\
\text { essay } \\
\text { competition, } \\
\text { debate, credit } \\
\text { accepted } \\
\text { abroad }\end{array}$ & $\begin{array}{l}\text { Quality of } \\
\text { delivery } \\
\text { system } \\
\infty \\
\text { Accreditation } \\
\text { and } \\
\text { affiliations }\end{array}$ & \\
\hline
\end{tabular}

Source: Authors' construction. 


\section{Conclusions}

The paper discusses the current status and related problems of the private universities in Bangladesh. Existing higher education scenario indicates that they have high potential, but it is likely that they have to go a long way to meet the social expectations. To actualize their potential, the government must provide necessary support and play the role of an effective facilitator. On their part, to excel in providing higher education in Bangladesh amid the challenges of the $21^{\text {st }}$ century, the private universities to follow and implement some broad strategies. For instances, they should offer, at reasonable costs, a set of academic programs/curricula leading to degrees that meet the needs of the students. Again, at the initial stage they should not go for rapid expansion of educational programs. Before diversification, strengthening and consolidating the degree programs that have already been introduced are required. Moreover, the universities should give priority to disciplines relevant to the needs of emerging social requirements of Bangladesh.

Similarly, for ensuring quality education they have to undertake a whole lot of steps. For instances, they have to update curriculum by academics par excellence regularly to cope with national and global development. Likewise, the teaching method should include case study, project, workshop, brainstorming, etc. along with lecture method by the qualified teachers. To ensure that the teachers who could command respect and confidence of the students and parents are to be hired on a full-time basis. In the process, a faculty development program should be in place in a long-term strategic plan. But instituting high-quality research programs and getting publications done by the faculty also play a role in quality teaching. For better participation and effective teaching in the limited class hours, a limited class-size should enhance the closer relationship between teachers and students.

At the same time, the quality level of student-inputs affects the graduate-outputs. So, strict admission criteria have to be applied for input selection which will increase the credibility of the university as well. The university should develop links with national and international organizations for providing internship to graduating students with hands-on-experience to prepare them for future placement in the same or other organizations at the end of their study. Not only that, the private universities should provide scholarship and financial assistance to students including the poor segment of the society keeping in mind the social realities of Bangladesh. Following the practices in developed countries, private universities may introduce Work-Study Programs, which could assuage the financial stress to a large extent on both the students and the administration. Besides enriching the students' experiences, this would give them confidence and a sense of the dignity of labor.

The role of adequate hard- and soft-infrastructure for quality education seems to have largely overlooked by the private universities in Bangladesh. A campus with adequate land area and built-in spaces for accommodating various sizes of classrooms, academic and co-curricular activities, libraries, seminar-halls, auditorium, laboratory, staff and students' common rooms, canteen, etc. should be a priority for a university establishment. External image building through collaboration with as many nationally and internationally reputed universities and acquiring accreditation from accreditation bodies would enhance the image of the university. This should be in addition to the current requirement of having the approval of the UGC as per the provision of the PUB-2010.

In addition, quality assurance calls for good governance. Operational efficiency of individual universities greatly determines the quality of education they impart. It depends on the working relationships between the government/UGC, the founders of the universities and university administration. Unless these relationships are well designed and clearly defined, the management efficiency of the universities will certainly suffer. In governance again, the excessive involvement of the owners is vitiating academic environment of many of the universities. As knowledge industry has a very special nature, the private universities should not be governed by the private corporate style.

The government and UGC have an active role to play here. The private universities should encourage the quick formation of the proposed Accreditation Body of the UGC. Moreover, as planned by UGC, all universities should go for completing the establishment of quality assurance cell to design, guide and facilitate the quality assurance activities within the institution.

\section{References}

Ahmed, Mofiz Uddin et al. (2002). "Quality Assurance in Higher Education in Bangladesh by Open and Distance Mode," U.G.C, Proceedings of the International Seminar on Quality Assurance in Higher Education in Bangladesh, March 4-6, pp. 35-58.

Barai, Munim Kumar. (2006). "Issues in Quality Assurance in Higher Education and the Private Universities in Bangladesh," Bangladesh Society for Total Quality Management, 1st Annual Convention Papers. September 15-16: pp.78-90.

Chowdhury, Anwarullah. (2002). "Quality Assurance in Public Universities of Bangladesh: Problems and Prospect," U.G.C, ibid, pp. 157-162.

Dean, James W., Jr. and James R. Evans. (1994). Total Quality: Management, Organization, and Strategy, St. Paul, MN, USA: West Publishing Co.

Haque, M Shamsul. (2014). "Private universities in Bangladesh: An effective innovation in higher education," The Daily Star. Dhaka: May 29. 
Hope, Andrea. (2002). "Quality Assurance Practices Around the World and the Initiative of the Commonwealth of Learning to Promote Best Practices," U.G.C, ibid, pp.13-22.

Harris, R.W and A Sullivan. (2002). "Quality Assurance in Higher Education: The English Experience," U.G.C, ibid, pp.23-34.

King, Roger. (2003).The Rise and Regulation of For-Profit Higher Education, London: Observatory on Borderless Higher Education, December.

Levy, Daniel C. (2002). Unanticipated Development: Perspectives on Private Higher Education's Emerging Roles, Albany: PROPHE, Education Administration and Policy Studies, State University of New York.

Mahmud, Monjur Morshed. (2002). "Quality Assurance in Public Universities of Bangladesh: Status Problems and Prospect," U.G.C, ibid, pp. 129-156.

Michelsen, Gunnar Guddal. (2008). "The rise of private higher education in Senegal: An example of knowledge shopping?" in Debbie Epstein, Rebecca Boden, Rosemary Deem, Fazal Rizvi and Susan Wright (eds). (2008). Geographies of Knowledge, Geometries of Power: Framing the Future of Higher Education. World Yearbook of Education 2008, Routledge London. pp. 280-298.

Parasuraman, A., V.A. Zeithaml and L.L. Berry. (1988). "SERVQUAL: A Multiple-Item Scale for Measuring Consumer Perceptions of Service Quality," Journal of Retailing, Vol. 64, No. 1, Spring, pp. 12-20.

Prasad, V.S. (2002). "Quality Assurance in Higher Education in a Global Era: The Concerns and the Approaches," U.G.C., ibid, pp. 9-12.

Siddiqi, Hafiz G A. (2002). "Quality Assurance in Conventional Private Universities of Bangladesh: Its Status, Problems and Strategic Plans," U.G.C, ibid, pp. 163-186.

Thaver, Beverley. (2003). 'Private higher education in Africa', in D. Teferra and P. G. Altbach (eds) African Higher Education: An International Reference Handbook, Bloomington: Indiana University Press.

UGC (University Grants Commission), Annual Reports, various issues.

UGC. (2004). Annual Report 2004, UGC, Dhaka.

UGC. (2013). Annual Report 2013, UGC, Dhaka.

UGC. (2014). Institutional Quality Assurance Cell Operations Manual, Higher Education Quality Enhancement Project (HEQEP,) UGC, Dhaka; August.

UNICEF. (2000). Defining Quality in Education, Paper Presented by UNICEF at the meeting of The International Working Group on Education, Florence, Italy: Program Division Education, NY: P4 